\title{
The Diffusion of Educational Ideas among International Organizations: An Event History Analysis of Lifelong Learning, 1990-2013
}

\author{
MIKE ZAPP AND CLARISSA DAHMEN
}

\begin{abstract}
This article investigates the precipitants of the diffusion of lifelong learning among 88 governmental and nongovernmental international organizations from 1990 to 2013 within an event history framework. Research on the diffusion of educational ideas among and within international organizations usually uses small-n approaches. This work looks at the large-scale interorganizational diffusion of lifelong learning, an important concept that has until now only been analyzed at the national level where worldwide adoption has occurred around the millennium. This study identifies astonishingly rapid and wide contagious diffusion of lifelong learning originating in core large, global, and Northern organizations with a long history before spreading to smaller, regional, more peripheral and younger ones. Recently, established organizations enter a world rife with legitimized educational models ready to be adopted. This article argues that the massive interest in lifelong learning needs to be explained by the highly institutionalized character of education and the hierarchical organization of the field around core and peripheral knowledge producers.
\end{abstract}

\section{Introduction}

The early twentieth century saw the rise of international organizations (IOs) explicitly founded to promote education worldwide, such as the International Federation of Secondary Teachers (1912) and the World Association for Adult Education (1918), as well as what we call the international system, primarily represented by the League of Nations, the International Committee of Intellectual Cooperation (UNESCO's precursor), and the International Labor Organization (ILO). Since then, IOs have grown considerably in number and kind, particularly international nongovernmental organizations (Boli and Thomas 1999) including, since the 1950s, those dealing with education. Thus, 33 intergovernmental organizations and 125 nongovernmental organizations signed the World Declaration on Education for All (EFA) in 1990, and overall international education funding ${ }^{1}$ increased by almost US $\$ 10$ billion from 1995 to 2012 (OECD CRS 2014).

${ }^{1}$ Including all educational sectors and all donors (bilateral, multilateral, and private).

Received January 8, 2016; revised May 16, 2016, and September 28, 2016; accepted October 31, 2016; electronically published June 23, 2017

Comparative Education Review, vol. 61, no. 3.

(C) 2017 by the Comparative and International Education Society. All rights reserved. $0010-4086 / 2017 / 6103-0005 \$ 10.00$ 
Growing interest in education is also reflected in what has come to be called "lifelong learning," a widely used label for a diverse bundle of ideas of how to reform existing training and education systems. Surprisingly fast, countries around the world have started to embrace this label in formal statements and policy initiatives (Jakobi 2006).

At the level of IOs, we find a large-scale diffusion of lifelong learning in the European Union, which established the Center for Research on Education and Lifelong Learning in 2005. The Organization for Economic Cooperation and Development (OECD) announced Lifelong Learning for All in 1996 already and the World Bank (WB) declared Lifelong Learning in the Global Knowledge Economy in 2003. In 2006, UNESCO's Institute of Education was renamed the UNESCO Institute for Lifelong Learning. In 2015, at the World Education Forum in the Republic of Korea, lifelong learning was emphasized again as the priority of global efforts in educational development by leaders from nation-states and IOs.

Yet, despite the considerable theoretical and empirical literatures on emerging global governance structures in education across the life course, some crucial questions remain unanswered. These revolve around the (1) scope of the field (its size and composition), (2) its internal dynamics (the flow of ideas and diffusion mechanisms), and (3) its assumed hierarchy (core vs. peripheral organizations).

First, virtually all studies on education and, more recently, lifelong learning focus on a small set of organizations, notably the four mentioned above, plus the ILO. This narrow analytic scope largely obscures phenomena in other geographic areas and other types of organizations. Thus, here we measure the scope of this growing field by analyzing the diffusion of lifelong learning across 88 international organizations active during the period 1990 to 2013. We argue that these IOs, particularly the new organizations, have made this diffusion a truly global pattern and, in doing so, corroborate theories of global isomorphic change at the level of national education systems as proposed by world polity theory (Meyer et al. 1997). If we assume that IOs have a growing impact on national educational policy making worldwide, it seems imperative to chart their evolution and specify their role as educational actors in regional and organizational contexts in order to help explain such increasing standardization and resulting convergence.

Second, in explaining IOs' interest in education, most accounts focusing on the "movement of ideas" either take the functionality of education and lifelong learning for granted or they dismiss IOs' work as strategies to impose their ideology on national policy makers or other organizations. In contrast, this article understands education and lifelong learning as primarily institutional, deeply embedded within an increasingly global cultural fabric, and its wide diffusion as a mimetic process beyond evidence of functional value (Chabbott 2003). Such a cultural perspective not only helps explain cross- 
national isomorphic change in education but also implies a shift in our understanding of IOs from state-centric instruments and ideological agenda setters to autonomous drivers of social change.

Third, while many studies stress the importance of organizations such as UNESCO, OECD, WB, and ILO, they remain descriptive. We test the impact of these organizations on the idea of lifelong learning within the field, specifying which organizational properties explain a core-periphery hierarchy among IOs.

By examining the social structure and diffusion mechanisms within this worldwide field of IOs, this article contributes to two bodies of research. First, it links the literature on global educational governance with organization theory by analyzing IOs as a specific type of organizational actor. Here, IOs are treated as a level of analysis, focusing on their structural properties such as type (e.g., governmental vs. nongovernmental), size, location, and age. Second, it adds interorganizational processes to the (comparative) educational governance discussion by investigating mutual awareness and "contagion" among IOs around the concept of lifelong learning. An event history analysis enables the assessment of the precipitants and temporal patterns of the fast and wide adoption of the concept and, in a more sophisticated and innovative extension, to track diffusion paths as variants of such "contagion" based on interorganizational awareness and mimesis. Such an analysis helps identify the potential hierarchy within the field in terms of authority, with some organizations more central than others as suggested by the strong concentration in the literature on a few organizations.

\section{Perspectives on Global Educational Governance}

In recent years, education research has systematically introduced global dimensions into the analysis of educational governance and policy making. Important macro-approaches on the role of IOs in globalizing education include Dale's (2005) pluri-scalar governance of education in the European Union, where governance activities such as funding, ownership, provision and regulation are reshuffled along subnational, national, and supranational levels. Mundy $(2006,2007)$ proposes "educational multilateralism," describing IOs as "a new venue for political contests over shared norms and institutions" (2007, 20). In a similar functionalist, though less critical vein, Parreira do Amaral (2010) sees an "international regime" rising in education with governmental and nongovernmental, national, and international organizations institutionalizing education globally.

Further, researchers from neighboring fields such as comparative and international (development) education interested in educational policies examine the roles of certain international actors. Here, IOs are treated either 
as "hard" players that regulate, fund, and impose education by tricking states into new policies (Dale 2005; Scherrer 2007) or, more softly, as "teachers of norms" (Finnemore 1993) or "knowledge brokers" (Jakobi 2006). In the latter case, governance is carried out, for example, through coordination or comparison (Martens and Niemann 2010) or agenda setting (Jakobi 2006) with the whole field in a "metrological mood" (Power 2004, 766; also see Wiseman and Baker 2005). Such approaches are highly useful in providing this new perspective on how to rethink educational planning and organization in a globalized world, acknowledging the critical importance that IOs have gained in the past two decades (Mundy and Ghali 2009).

At the same time, they share some major theoretical and analytical blind spots, exacerbated in case studies on individual IOs. First, the analytical logic is usually vertical instead of horizontal. How do (mostly powerful) states influence IOs and (mostly powerful) IOs influence (mostly weak) states? In this sense, analytical logics are either upward or downward. Rarely do we ask what happens within individual IOs and between them. This vertical logic is evident in the three macro-approaches (critical, functionalist, and institutional) and in almost all research on policy movements (imposition, learning, lending, borrowing, transfer, etc.; see, e.g., Jakobi 2012; Steiner-Khamsi 2012).

Yet we know too little about the movement of ideas among international actors themselves and fail to consider the possibility that certain educational models might originate at the IO level. The vertical logic of analysis also ignores the potential role of IOs in diffusing, elaborating, incentivizing, and implementing ideas globally, thus directly contributing to the worldwide isomorphism observed.

Second, such a vertical logic becomes even more problematic if we take the assumed "globality" of much educational phenomena at face value while limiting the analytical focus to a very small sample of (albeit global) organizations (e.g., UNESCO), ignoring recent organizational phenomena emerging in virtually all world regions. As mentioned above, research on globalized education is marked by an excessive interest in the "Big Five," that is, UNESCO, WB, OECD, EU, and (less frequently) ILO (2007). Occasional references to the World Trade Organization (WTO; Scherrer 2007) or the Commonwealth of Learning (COL; Daniel 2009) correct this picture only marginally. Focusing on the Big Five has its reasons. These organizations raise most of the funds, possess most of the expertise, pursue the most thorough strategies, and might, consequentially, exert most of the influence in the field; that is, they constitute its center. However, such concentration appears untenable for understanding comprehensively why educational models have been carried to every corner of the globe so rapidly. While scholarship on global social policy has already produced a more nuanced picture of potential actors of different types operating at different levels, research on education and on lifelong learning in particular has ignored burgeoning regional bodies and develop- 
ment banks, bilateral donor agencies, nongovernmental business, labor and philanthropic organizations, which are part of a "transnational welfare mix" in global social governance (Deacon 2007; Yeates 2008). Analyses of social policy, while stressing an overall increase at the international level, point to conflicting positions and hierarchical structures within the IO field, with some strong IOs setting the agenda and others either contesting or following it. This article aims to expand the analytical scope in the field of education, assessing international organizations' general growth, internal dynamics, and hierarchy.

\section{Educational Diffusion among International Organizations}

Sociological neoinstitutionalism offers an approach to understand the emergence of global educational governance and the role of IOs markedly different from the functionalist and critical perspectives introduced above. Examining the role of IOs in the EFA initiative, Chabbott (2003) finds a "global organizational field of educational development," understood as "systematic efforts to improve education systems in order to support more general socioeconomic development in less industrialized countries" $(2003,15)$. Her analysis is interested in the global, that is, IO level, including various organizational types (e.g., governmental vs. nongovernmental), their networks, and governance mechanisms. She argues that the differences between educational governance in a less industrialized context and in a more industrialized one have become differences of degree rather than of kind. Further, she identifies "belief systems" that bind together the members (IOs) of the organizational field (Scott 1994). The belief systems in the global organizational field of educational development take the form of dominant themes in international discourses on development and the role of education. The dominating themes in the early 1990s were inscribed in the EFA agenda with its strong focus on the inclusion of underprivileged groups, universal primary and secondary education, educational quality, and the eradication of illiteracy (Chabbott 2003). Has lifelong learning become one of these dominant themes since then?

Chabbott (2003) further argues that an organization's role in knowledge production helps to explain the diffusion of education and development models among IOs by structuring the field into core and periphery. While the knowledge producers (large, global, governmental and long-standing IOs with professional staff, professional schools, journals and so on) sit at the core, the knowledge users that depend on this knowledge (smaller, regional and more recent IGOs and INGOs) occupy more peripheral positions. Such structuration has led to isomorphic processes in positions and practices among highly diverse actors in the field as innovations flow among field members from core organizations to more peripheral ones. This resonates with the main tenets 
from neoinstitutionalist organization theory (Powell and DiMaggio 1991). As organizations become more similar, coercive mechanisms (e.g., financial leverage) play a smaller role than is often assumed. Instead, normative (e.g., standard-setting) and mimetic (e.g., cognitive, imitative) processes in which professionals create and spread authoritative standards, expectations, and stocks of knowledge (e.g., common development models, common organizational principles, and common action frameworks) stand out, thus facilitating transfer and implementation among organizations and nation-states as well as among IOs (Chabbott $(2003,92)$. This perspective complements the Big Five focus in the wider literature but fine-tunes analysis of how interorganizational influence occurs (i.e., mimesis) and its consequences (i.e., isomorphism). Moreover, while the large global IOs set the agenda, smaller INGOs, regional IGOs, and bilateral development agencies work the "grass roots" and "on the ground," serving as local catalysts and transmitters for global ideas.

In general, world polity theory emphasizes that a growing number of INGOs and IGOs provide rationalized accounts of social organization serving as "theorists" or "others" in an integrated world society (Meyer et al. 1997; Ramirez et al. 2016). Here large-scale social change at the national level works with IOs representing world goals of progress and justice, as well as world principles of rationality and universality, which they translate into theorized models of educational reform (Strang and Meyer 1993; Drori et al. 2003; Bromley 2010).

While these accounts offer a theoretical frame to understand the role of IOs as a "consultative" actor in general, they concede similar conceptual relevance to all organizational forms of this kind of actor. We argue that we need a more fine-grained empirical analysis of how these various organizations interact and evolve over time. Is the global organizational field of education composed of organizational members that share the same "belief system" and the same degree of mutual awareness across types (e.g., governmental vs. nongovernmental IOs), size (large vs. small IOs), and areas (Western vs. Southern IOs)? Or conversely, do ideas diffuse only within these specific channels in a stratified organizational field?

\section{Lifelong Learning}

Despite its current prominence, lifelong learning should neither be seen as a novel idea nor as historically detached from IOs' early work in education. The late 1960s and early 1970s saw three concepts_-"permanent education," "lifelong education," and "recurrent education"-which are usually considered conceptual precursors of the current lifelong learning concept, introduced by three IOs, the Council of Europe (COE), UNESCO, and OECD (Tuijnam and Boström 2002; Milana 2012). 
Most current contributions define lifelong learning as an idea impacting adult education, in both vocational and liberal forms (Field 2006; Schemmann 2007; Jarvis 2010), as well as higher education. More rarely, lifelong learning is understood as early childhood care and education (ECCE) because ECCE lays the foundations for later education (Jakobi 2006).

It has also been argued that the tendency to replace education with learning "depoliticizes" the field and threatens to remove significant issues of equity and resource allocation from the research and policy agenda (Duke 1999)..$^{2}$ Using the word learning implies that the state backs out as guarantor of equality (of opportunities and results) and failure becomes individualized (Field 2006; Milana 2012). Such concerns places lifelong learning in a market or neoliberal model where overriding goals are economic growth and employability. In contrast, an emancipatory or social justice type of lifelong learning would "push the notion of equality of opportunity and life chances through education in a democratic society" (Schuetze and Casey 2006, 282). It is these questions around educational goals, funding, and the role and responsibilities of the individual learner that might turn lifelong learning into "an explosive policy issue" entailing the potential to reflect our "way of thinking about and structuring our society's approach to education" (Field 2006, 17). Either way, lifelong learning has become "one of the most remarkable features of the education policy discourse, nationally and internationally, in the past decade" (Papadopoulos 2002, 39).

As we will show, lifelong learning has become the dominant theme on the international educational agenda of the 2000s, having seen rapid worldwide diffusion and affecting policies in pre-primary, higher and adult education at the national level, which can be attributed partially to the OECD (table 1; Jakobi 2006).

While diffusion at the national level has been thoroughly investigated, the same phenomenon beyond nation-states remains underspecified. How does the idea diffuse at the level of international organizations around the world? Lifelong learning as conceptualized by UNESCO, EU, OECD, the WB, and ILO is understood, ${ }^{3}$ but literature is scarce beyond the Big Five. Where comparative case analyses have been done, there is agreement on increasing convergence of positions toward lifelong learning (e.g., on UNESCO, EU, and OECD, see Rutkowski 2007 and Schemmann 2007; on the WB and ILO, see Jakobi 2007).

\footnotetext{
${ }^{2}$ See also Rivera (2009) for an insider's account on the early quarrel about the terminology at the 1976 UNESCO conference on Lifelong Education. Education was proposed by European and learning by Anglophone educationalists.

${ }^{3}$ See Dale (2005); Papadopoulos (2006); Rutkowski (2007); Lee et al. (2008); Rivera (2009); Schuller (2009); Milana (2015); and Rubenson (2015).
} 
DIFFUSION OF EDUCATIONAL IDEAS AMONG INTERNATIONAL ORGANIZATIONS

TABLE 1

Diffusion of the Idea of Lifelong Learning (Jakobi 2006)

\begin{tabular}{lcclll}
\hline & $1971^{\mathrm{a}}$ & $1993 / 94$ & 1996 & 2001 & 2004 \\
\hline $\begin{array}{l}\text { Percentage of countries referring to LLL } \\
\quad \text { (1996-2004 cumulated) }\end{array}$ & 4.41 & 38.36 & 60.5 & 74.6 & 79.8 \\
Countries analyzed (1996-2004 cumulated) & 136 & 73 & 43 & 71 & 99 \\
Number of countries referring to LLL & 6 & 28 & 27 & 37 & 59 \\
Percentage of countries referring to LLL & 4.41 & 38.36 & 60.5 & 72.5 & 72 \\
Countries analyzed & 136 & 73 & 43 & 51 & 82 \\
\hline
\end{tabular}

${ }^{a}$ Refers to data around 1969. Source: Policy reports of various years.

This article, while documenting the influence of the Big Five, will investigate change in the educational discourse beyond the Big Five and will detail diffusion effects in a highly heterogeneous field.

\section{Methodology}

The following hypotheses guide our analyses:

Diffusion of Lifelong Learning

H1: There has been a significant increase in the adoption of lifelong learning in the period 1990-2013 among selected organizations as measured by the number of first-time references per year.

Here we go beyond Chabbott's (2003) demonstration of the emergence of an international organizational field and the ties of the members within it to document the diffusion of ideas within it, paralleling study of the diffusion of lifelong learning at the level of national states (Jakobi 2006). Interest in and adoption of lifelong learning is defined by the first explicit reference to the concept in organizations' official documents, analyzed as the dependent variable (DV) in a simple linear regression model.

Timing of Diffusion

H2: The timing of adoption is influenced by an organization's founding year, staff, type, or geographical area.

We are interested in the explanatory power of organizations' properties in the diffusion process. Our hypothesis concerns diffusion effects in a heterogeneous field. The dependent variable in all of our analyses is the hazard rate for referring to lifelong learning for the first time during consecutive years of observation, as observed in each organization's published documents. The hazard rate describes the probability of an event occurring within a given time interval. 
Our independent variables reflect key findings from (diffusion) research in organization and macrolevel studies on the importance of organizations' structural properties . ${ }^{4}$ They include the type of organization, average number of staff during the observation period, location of the organization, and the organization's age or founding year. ${ }^{5}$ These variables define core and periphery of our organizational field, an important analytical thrust in internal field structuration (Chabbott 2003). In addition, as the literature shows, IGOs and Western business INGOs have been active promoters of lifelong learning. We can thus state more precise hypotheses based on this distinction:

H2.1: Older IOs (i.e., the core) are more likely to adopt lifelong learning.

H2.2: Larger IOs with more staff (i.e., the core) are more likely to adopt lifelong learning.

H2.3: Intergovernmental organizations and international non-governmental business organizations (i.e., the core) are more likely to adopt lifelong learning.

H2.4: Global organizations and Western organizations (i.e., the core) are more likely to adopt lifelong learning.

To gauge the diffusion of lifelong learning as a concept, the occurrence of usage of the relevant terms is measured utilizing event history analysis (EHA) (or survival analysis). EHA analyzes and explains the duration of time until an event happens, in order to compare time-to-event between two or more groups (of IOs in this case) and to assess the influence of the respective covariables. The technique is best suited to study discrete events occurring across time, while accounting for right-censored cases, that is, events not occurring until the end of the observation period (Tuma and Hannan 1984; Strang and Tuma 1993).

In order to test these hypotheses, we estimate survival model-based hazard functions which describe how the hazard rate changes over time at baseline levels of covariates and how the size of the hazard rate (DV) depends on explanatory covariates (organizational type, location, average number of staff, and age) (Aalen et al. 2008).

\footnotetext{
${ }^{4}$ See Stinchcombe (1965); DiMaggio and Powell (1983); Hannan and Freeman (1984); Wejnert (2002); Scott (2013).

${ }^{5}$ Staff was preferred over resources as it provides a much more comparable variable due to the problems with different (and sometimes historical) currencies, special drawing rights and budget reporting rules. Real founding years were only used for organizations founded after 1990, for all others founding was set to 1989 , the year prior to observation period
} 
DIFFUSION OF EDUCATIONAL IDEAS AMONG INTERNATIONAL ORGANIZATIONS

Diffusion by Contagion at the Global Level

H3: Diffusion of lifelong learning among the selected organizations is explained by contagion.

Diffusion will be analyzed as a "contagious" or "epidemic" process (the methodological concept for "mimesis") through which ideas, innovations, or practices are transmitted through prior action by other actors (Borgatti and Foster 2003; Rogers 2003). We model the adoption of lifelong learning as a function of previous references, introducing the notion of actual diffusion (Strang and Meyer 1993). The focus is the rise of lifelong learning over time in a dynamic field of potential adopters. Longitudinal methods can explicitly recognize and handle the complex time structure behind the diffusion process (Nazio 2008). To account for this time structure, we split the data set along individual organizations and episodes. Each time a lifelong learning-related event occurs, the episode is split up to avoid overlapping with prior events. Each event marks the end of an episode and the beginning of a new one.

In order to test whether the diffusion of lifelong learning occurs via contagion, we run Cox regressions that describe how the hazard ratio (DV) varies in response to the explanatory covariate (prior references). The aim is to test whether prior references increase the risk of contagion and inspire other organization to refer to lifelong learning as well.

Diffusion by Contagion through Specific Channels

H4: Diffusion by contagion occurs more strongly among organizations within the same area, type, and age group.

Here we add "social structure" to the diffusion process (Strang 1991). An idea is communicated through certain channels or organizational sets within the wider field (Scott 2013), that is, among members of an "imagined" social community or, conversely, an imagined world polity beyond any specific channels. It has been shown that culturally defined similarity spurs diffusion (see Strang and Soule [1998] for a review), so we use organizations' structural properties (type, size, age) as channel variables. These characteristics are used to model diffusion effects as a social (and heterogeneous) process along specific channels assuming that lifelong learning spreads faster and more frequently among organizations with the same features, as they are more aware of each other.

Conversely, we may find low importance of specific channels and a stronger case for a unified world polity with IOs sharing the same "belief system" despite varying structural properties. To account for these social processes, we also separate each episode that marks the occurrence of an event (reference to lifelong learning) in the same channel. We estimate Cox regressions to examine whether the hazard ratio (DV) changes in response to the 
explanatory covariates (prior references by the respective organizations), and thus to test whether contagion occurs within specific channels (e.g., a southern organization inspiring other organizations in the same area) or at a global level.

Diffusion as an Effect of the Big Five

H5: Reference to lifelong learning by UNESCO, EU, OECD, WB, and ILO have a significant effect on subsequent references by other organizations.

Acknowledging the prominent role of the Big Five in global educational governance and the emergence of lifelong learning, we test their specific contribution to the diffusion of the concept within the organizational field studied.

Cox regressions are used to examine whether the hazard ratio (DV) changes in response to the explanatory covariates (prior references by UNESCO, EU, OECD, WB, and ILO in their so-called flagship publications). This tests whether the Big Five inspire other organizations to refer to lifelong learning.

\section{Sample and Data}

Sampling IOs is highly problematic for several reasons. First, the exact number of this kind of organization is not certain. Second, competing definitions of what an international organization is complicates data collection. Third, sources from which to obtain reliable information on IOs are limited. ${ }^{6}$ We therefore selected IOs based on several overlapping and mutually corroborating criteria.

First, we used as a main source the Yearbook of International Organizations (YIO) published by the Union of International Associations (UIA). Since 1953, the Yearbook has been the United Nation's official registry of IOs and has a mandate to have complete coverage of all kinds of IOs. The current online data set contains information on roughly 68,000 IOs in 300 countries and territories, making it the most extensive directory of IOs (UIA 2016). Generally, the YIO is highly reliable, consistent over time and has extensively been used in research; however, coverage is variable, especially for smaller organizations. We filled data gaps (e.g., staff, publications) by contacting organizations directly.

Second, all organizations are international or internationally oriented, as documented in their mission statements (taken from YIO).

Third, all organizations pursue goals of progress, development, growth, and betterment of society. These notions have become almost synonymous with education in modern societies (Boli et al. 1985; Ramirez and Boli 1987).

${ }^{6}$ See Bromley (2010) for a more detailed account on the challenges involved in sampling IOs. 
Organizations' interest in these goals provides a proxy for interest in education.

Fourth, we included previously noted studies that already investigated work done by influential organizations such as UNESCO, OECD, EU, WB, ILO, World Trade Organization, and the Council of Learning.

Fifth, we include types of organizations that have so far been completely outside of the scope of the relevant literature on education and lifelong learning but are prominent in global social policy studies such as regional IGOs and philanthropic INGOs (Yeates 2008).

Sixth, we include labor unions and business associations because, even though they seem at first glance to have no overt and direct interest in educational matters, they have nonetheless started to incorporate education into their operational portfolio.

Seventh, as an exploratory avenue, we include development agencies. Reflecting true commitments, we consider the total aid volume for education, which has been rising continuously since the 1990s. Here, the largest donors were selected based on OECD data (OECD CRS 2014).

Based on these criteria, the initial sample contained many more organizations, which we reduce to 88 because additional information needed for analysis (e.g., staff) could not be obtained; online access to documents was not available, and direct requests remained unanswered.

Table 2 provides a complete list of organizations included, along with information on type, foundation year, area, and abbreviation. Following the definitions from the Yearbook of International Organizations, the organizations selected can be distinguished by their type as:

(1) Multilateral intergovernmental organizations (IGOs) $(N=11)$.

(2) Multilateral regional intergovernmental organizations (regional IGOs) $(N=30)$.

(3) Multilateral regional, financial intergovernmental organizations (development banks) $(N=9)$.

(4) Bilateral internationally oriented national organizations (development agencies $)(N=9)$.

(5) International nongovernmental organizations (INGOs) $(N=29)$.

(5.1) International business organizations (business INGOs).

(5.2) International labor organizations (labor INGOs).

(5.3) International philanthropic organizations (philanthropic INGOs).

Our sample is neither exhaustive nor representative, but it takes into account the heterogeneity of the field with regard to location (including all areas), type (including diverse types), and age (including old and new).

An organization's interest in and adoption of lifelong learning is defined as an explicit reference to the concept in organizations' official documents 
TABLE 2

Sample of Organizations with Properties and Year of Adoption of Lifelong Learning (Own Account)

\begin{tabular}{|c|c|c|c|c|c|}
\hline Organization & Abbrev. & Founded & Type & Area & $\begin{array}{l}\text { Year of } \\
\text { Adoption }\end{array}$ \\
\hline $\begin{array}{l}\text { United Nations Educational, Scien- } \\
\text { tific, and Cultural Organization }\end{array}$ & UNESCO & 1945 & IGO & G & 1990 \\
\hline European Union & $\mathrm{EU}$ & 1952 & Regional IGO & $\mathrm{N}$ & 1993 \\
\hline United Nations Children's Fund & UNICEF & 1946 & IGO & G & 1995 \\
\hline $\begin{array}{l}\text { Organization for Economic } \\
\text { Cooperation and Development }\end{array}$ & OECD & 1960 & IGO & $\mathrm{N}$ & 1996 \\
\hline World Health Organization & WHO & 1948 & IGO & G & 1998 \\
\hline Asia-Pacific Economic Cooperation & APEC & 1989 & Regional IGO & M & 1999 \\
\hline Bill and Melinda Gates Foundation & Gates Foundation & 1999 & $\begin{array}{l}\text { Philanthropic } \\
\text { INGO }\end{array}$ & $\mathrm{N}$ & 1999 \\
\hline $\begin{array}{l}\text { World Bank: International Bank for } \\
\text { Reconstruction and Development } \\
\text { + International Development } \\
\text { Association }\end{array}$ & WB (IBRD+IDA) & 1945 & IGO & G & 1999 \\
\hline $\begin{array}{l}\text { Association of South East Asian } \\
\text { Nations }\end{array}$ & ASEAN & 1967 & Regional IGO & $\mathrm{S}$ & 2000 \\
\hline $\begin{array}{l}\text { European Association of Craft Small } \\
\text { and Medium-Sized Businesses }\end{array}$ & UEAPME & 1979 & $\begin{array}{l}\text { Business } \\
\text { INGO }\end{array}$ & $\mathrm{N}$ & 2000 \\
\hline Ford Foundation & Ford Foundation & 1936 & $\begin{array}{l}\text { Philanthropic } \\
\text { INGO }\end{array}$ & $\mathrm{N}$ & 2000 \\
\hline $\begin{array}{l}\text { International Confederation of Free } \\
\text { Trade Unions }\end{array}$ & ICFTU & 1949 & Labor INGO & G & 2000 \\
\hline International Labour Organization & ILO & 1919 & IGO & G & 2000 \\
\hline $\begin{array}{l}\text { Organization of Eastern Caribbean } \\
\text { States }\end{array}$ & OECS & 1981 & Regional IGO & $\mathrm{S}$ & 2000 \\
\hline Union Network International & UNI & 2000 & Labor INGO & G & 2000 \\
\hline $\begin{array}{l}\text { Business Industry Advisory } \\
\text { Committee }\end{array}$ & BIAC & 1962 & $\begin{array}{l}\text { Business } \\
\text { INGO }\end{array}$ & $\mathrm{N}$ & 2001 \\
\hline European Round Table & ERT & 1983 & $\begin{array}{l}\text { Business } \\
\text { INGO }\end{array}$ & $\mathrm{N}$ & 2001 \\
\hline Organization of American States & OAS & 1948 & Regional IGO & M & 2001 \\
\hline EuropeAid & EUROPEAID & 2001 & Agency & $\mathrm{N}$ & 2002 \\
\hline $\begin{array}{l}\text { International Metalworkers } \\
\text { Federation }\end{array}$ & IMWF & 1893 & Labor INGO & G & 2002 \\
\hline Inter-American Development Bank & IADB & 1959 & Bank & M & 2003 \\
\hline $\begin{array}{l}\text { United States Agency for } \\
\text { International Development }\end{array}$ & USAID & 1961 & Agency & $\mathrm{N}$ & 2003 \\
\hline African Development Bank & AFDB & 1964 & Bank & $\mathrm{S}$ & 2004 \\
\hline $\begin{array}{l}\text { Department for International } \\
\text { Development }\end{array}$ & DFID & 1997 & Agency & $\mathrm{N}$ & 2004 \\
\hline World Federation of Trade Unions & WFTU & 1949 & Labor INGO & G & 2004 \\
\hline Pacific Island Forum & PIF & 1971 & Regional IGO & $\mathrm{S}$ & 2005 \\
\hline African Union & AU & 2001 & Regional IGO & $\mathrm{S}$ & 2006 \\
\hline Agence Française de Développement & AFD & 1941 & Agency & $\mathrm{N}$ & 2006 \\
\hline British Wellcome Trust & Wellcome & 1936 & $\begin{array}{l}\text { Philanthropic } \\
\text { INGO }\end{array}$ & $\mathrm{N}$ & 2006 \\
\hline Commonwealth of Learning & $\mathrm{COL}$ & 1988 & Regional IGO & $\mathrm{M}$ & 2006 \\
\hline $\begin{array}{l}\text { Council of Europe Development } \\
\text { Bank }\end{array}$ & CEB & 1956 & Bank & $\mathrm{N}$ & 2006 \\
\hline Economic and Social Council & ECOSOC & 1945 & IGO & G & 2006 \\
\hline $\begin{array}{l}\text { European Trade Union } \\
\text { Confederation }\end{array}$ & ETUC & 1958 & Labor INGO & $\mathrm{N}$ & 2006 \\
\hline International Monetary Fund & IMF & 1945 & IGO & G & 2006 \\
\hline Islamic Development Bank & IDB & 1975 & Bank & $\mathrm{S}$ & 2006 \\
\hline $\begin{array}{l}\text { South Asian Association for Regional } \\
\text { Cooperation }\end{array}$ & SAARC & 1985 & Regional IGO & S & 2006 \\
\hline
\end{tabular}


TABLE 2 (Continued)

\begin{tabular}{|c|c|c|c|c|c|}
\hline Organization & Abbrev. & Founded & Type & Area & $\begin{array}{l}\text { Year of } \\
\text { Adoption }\end{array}$ \\
\hline $\begin{array}{l}\text { Agencia española de Cooperación } \\
\text { Internacional para el Desarrollo }\end{array}$ & AECID & 1988 & Agency & $\mathrm{N}$ & 2007 \\
\hline Andean Community & CAN & 1996 & Regional IGO & $\mathrm{S}$ & 2007 \\
\hline Asian Development Bank & $\mathrm{ADB}$ & 1965 & Bank & M & 2007 \\
\hline Council of Europe & $\mathrm{COE}$ & 1949 & Regional IGO & $\mathrm{N}$ & 2007 \\
\hline $\begin{array}{l}\text { Japan International Cooperation } \\
\text { Agency }\end{array}$ & JICA & 2003 & Agency & $\mathrm{N}$ & 2007 \\
\hline $\begin{array}{l}\text { Organization of the Black Sea } \\
\text { Economic Cooperation }\end{array}$ & BSEC & 1992 & Regional IGO & S & 2007 \\
\hline $\begin{array}{l}\text { Southern African Development } \\
\text { Community }\end{array}$ & SADC & 1992 & Regional IGO & $\mathrm{S}$ & 2007 \\
\hline Stichting Nederlandse Vrijwilligers & SNV & 1965 & Agency & $\mathrm{N}$ & 2007 \\
\hline $\begin{array}{l}\text { United Nations Industrial } \\
\text { Development Organization }\end{array}$ & UNIDO & 1967 & IGO & $\mathrm{G}$ & 2007 \\
\hline World Trade Organization & WTO & 1995 & IGO & G & 2007 \\
\hline Eurasian Economic Community & EURASEC & 2000 & Regional IGO & M & 2008 \\
\hline $\begin{array}{l}\text { European Bank for Reconstruction } \\
\text { and Development }\end{array}$ & EBRD & 1991 & Bank & $\mathrm{N}$ & 2008 \\
\hline $\begin{array}{l}\text { European Federation of Public } \\
\text { Service Unions }\end{array}$ & EPSU & 1973 & Labor INGO & $\mathrm{N}$ & 2008 \\
\hline League of Arab States & LAS & 1945 & Regional IGO & $\mathrm{S}$ & 2008 \\
\hline Caribbean Community & CARICOM & 1973 & Regional IGO & $\mathrm{S}$ & 2009 \\
\hline East African Community & EAC & 2000 & Regional IGO & $\mathrm{S}$ & 2009 \\
\hline $\begin{array}{l}\text { Economic Community of West } \\
\text { African States }\end{array}$ & ECOWAS & 1975 & Regional IGO & $\mathrm{S}$ & 2009 \\
\hline Education International & EI-IE & 1993 & Labor INGO & G & 2009 \\
\hline $\begin{array}{l}\text { Gesellschaft für Internationale } \\
\text { Zusammenarbeit }\end{array}$ & GIZ & 2011 & Agency & $\mathrm{N}$ & 2011 \\
\hline Business Europe & $\mathrm{BE}$ & 1958 & $\begin{array}{l}\text { Business } \\
\text { INGO }\end{array}$ & $\mathrm{N}$ & 2012 \\
\hline European Metalworkers Federation & EMF & 1963 & Labor INGO & $\mathrm{N}$ & 2012 \\
\hline $\begin{array}{l}\text { International Chamber of } \\
\text { Commerce }\end{array}$ & ICC & 1920 & $\begin{array}{l}\text { Business } \\
\text { INGO }\end{array}$ & G & 2012 \\
\hline $\begin{array}{l}\text { International Trade Union } \\
\text { Confederation }\end{array}$ & ITUC & 2006 & Labor INGO & $\mathrm{G}$ & 2012 \\
\hline Union for the Mediterranean & UMF & 2008 & Regional IGO & M & 2012 \\
\hline $\begin{array}{l}\text { Partners in Population and } \\
\text { Development }\end{array}$ & PPD & 1994 & IGO & S & 2013 \\
\hline Central American Integration System & SICA & 1991 & Regional IGO & $\mathrm{S}$ & No date \\
\hline $\begin{array}{l}\text { American Howard Hughes Medical } \\
\text { Institute }\end{array}$ & Hughes & 1953 & $\begin{array}{l}\text { Philanthropic } \\
\text { INGO }\end{array}$ & $\mathrm{N}$ & No date \\
\hline $\begin{array}{l}\text { Intergovernmental Authority on } \\
\text { Development }\end{array}$ & IGAD & 1986 & Regional IGO & $\mathrm{S}$ & Never \\
\hline Agência Brasileira de Cooperação & $\mathrm{ABC}$ & 1950 & Agency & $\mathrm{S}$ & Never \\
\hline Bolivarian Alliance for the Americas & ALBA & 2004 & Regional IGO & $\mathrm{S}$ & Never \\
\hline $\begin{array}{l}\text { Building and Wood Workers } \\
\text { International }\end{array}$ & BWI & 1934 & Labor INGO & G & Never \\
\hline Carribean Congress of Labour & CCL & 1960 & Labor INGO & $\mathrm{S}$ & Never \\
\hline $\begin{array}{l}\text { Development Bank of Central } \\
\text { African States }\end{array}$ & DBCAS & 1975 & Bank & $\mathrm{S}$ & Nver \\
\hline $\begin{array}{l}\text { Dominican Republic-Central } \\
\text { America Free Trade Agreement }\end{array}$ & CAFTA & 2004 & Regional IGO & M & Never \\
\hline Economic Cooperation Organization & ECO & 1985 & Regional IGO & $\mathrm{S}$ & Never \\
\hline $\begin{array}{l}\text { General Confederation of Trade } \\
\text { Unions }\end{array}$ & GCTU & 1992 & Labor INGO & G & Never \\
\hline Indian Ocean Commission & IOC & 1982 & Regional IGO & $\mathrm{S}$ & Never \\
\hline $\begin{array}{l}\text { Indian Ocean Rim Associations for } \\
\text { Regional Cooperation }\end{array}$ & IOR-ARC & 1997 & Regional IGO & $\mathrm{S}$ & Never \\
\hline
\end{tabular}


TABLE 2 (Continued)

\begin{tabular}{|c|c|c|c|c|c|}
\hline Organization & Abbrev. & Founded & Type & Area & $\begin{array}{l}\text { Year of } \\
\text { Adoption }\end{array}$ \\
\hline $\begin{array}{l}\text { International Confederation of Arab } \\
\text { Trade Unions }\end{array}$ & ICATU & 1956 & Labor INGO & $\mathrm{S}$ & Never \\
\hline $\begin{array}{l}\text { International Federation of } \\
\text { Chemical, Energy, Mine and } \\
\text { General Workers Unions }\end{array}$ & ICEM & 1995 & Labor INGO & G & Never \\
\hline $\begin{array}{l}\text { International Textile, Garment and } \\
\text { Leather Workers Federation }\end{array}$ & ITGLWF & 1970 & Labor INGO & G & Never \\
\hline $\begin{array}{l}\text { International Transport Workers } \\
\text { Federation }\end{array}$ & ITF & 1896 & Labor INGO & G & Never \\
\hline $\begin{array}{l}\text { International Union of Food, } \\
\text { Agricultural, Hotel, Restaurant, } \\
\text { Catering, Tobacco and Allied } \\
\text { Workers A }\end{array}$ & IUF & 1920 & Labor INGO & G & Never \\
\hline Mercado Común del Sur & MERCOSUR & 1991 & Regional IGO & $\mathrm{S}$ & Never \\
\hline Nordic Development Fund & NDF & 1989 & Bank & $\mathrm{N}$ & Never \\
\hline $\begin{array}{l}\text { North American Free Trade } \\
\text { Agreement }\end{array}$ & NAFTA & 1994 & Regional IGO & $\mathrm{N}$ & Never \\
\hline $\begin{array}{l}\text { Organization for Democracy and } \\
\text { Economic Development }\end{array}$ & GUAM & 1999 & Regional IGO & $\mathrm{S}$ & Never \\
\hline Public Services International & PSI & 1907 & Labor INGO & $\mathrm{G}$ & Never \\
\hline $\begin{array}{l}\text { Saudi Arabian Mohammed bin } \\
\text { Rashid Al Maktoum Foundation }\end{array}$ & Maktoum F. & 2007 & $\begin{array}{l}\text { Philanthropic } \\
\text { INGO }\end{array}$ & $\mathrm{S}$ & Never \\
\hline Stichting INGKA Foundation & INGKA & 1982 & $\begin{array}{l}\text { Philanthropic } \\
\text { INGO }\end{array}$ & $\mathrm{N}$ & Never \\
\hline Union of South American Nations & UNASUR & 2004 & Regional IGO & $\mathrm{S}$ & Never \\
\hline West African Development Bank & BOAD & 1974 & Bank & $\mathrm{S}$ & Never \\
\hline
\end{tabular}

(table 2). Strictu sensu, we thus measure the occurrence of a terminological phenomenon but assume that there is conceptual value ascribed to it by organizations.

Documents were collected online from each organization's website using either web crawler tools, the internal website search engine, or direct correspondence with organizations. To ensure replicability, publicly available documents were used. The observation period starts with 1990, the beginning of the EFA initiative and a turning point in the history of global educational governance (Chabbott 2003), and ends in 2013. The document sample includes reports, project-related documents, press releases, statements and website content with clear organizational authorship. We consider all these types of documents as explicit organizational statements. As we required only one document for analysis (the first document in which the organization mentioned lifelong learning), differences in the total number of documents do not affect our analysis.

Key word search within documents was based on a defined dictionary in five languages (English, French, Spanish, Portuguese, and German) either 
automatically (Maxqda) or - if copy or scan quality was low as for older documents-manually.

Results

Interorganizational Diffusion of Lifelong Learning, 1990-2013

The large majority of organizations from the selected sample (63 out of 88 , or 71.5 percent) explicitly refer to the idea of lifelong learning in their documents. Based on internal search engine document counts, the four most productive organizations (UNESCO, EU, OECD, and WB) account for 74 percent (or 20,500) of lifelong learning documents $(27,720$ total number of documents referring to lifelong learning). Although this publication record reflects a core-periphery structure, a remarkably large number of organizations, which have been neglected in the literature on lifelong learning, have shown sudden interest in this novel educational concept. Among these, we find the whole array of organization types from the sample (table 2), from business (BusinessEurope, BIAC, and UEAPME), and labor organizations (UNI and EI) to development actors. Bilateral agencies are present (EuropeAid, USAID), as are development banks (AFDB and IADB). Each organization is listed in table 2 by founding date, type, and scope of activity.

Some regional bodies such as OAS, APEC, and CARICOM represent different world areas. In addition, the two latter organizations have certainly (at least implicitly) contributed to the discourse on lifelong learning even though they have been primarily seen as economic bodies. Particularly the regional bodies are also among the early adopters (APEC, ASEAN, OECS, and OAS).

In order to capture the dynamic of the diffusion process over the period 1990-2013, the first published document containing a reference to lifelong learning has been used as an approximate variable for the adoption of lifelong learning. While the starting year for the observation period had a priori been decided based on more theoretical suggestions (first EFA World Summit), the first document from the sample (UNESCO) was indeed published in 1990 where lifelong learning and lifelong education are still used in parallel (a situation that can only be found in EU documents from the years 1993 and 1995).

The adoption curve (fig. 1, dotted line) shows remarkably rapid diffusion in the observation period $\left(P=.048 ; R^{2}=.166\right)$ with global spread being slow until the millennium, when it achieves an initial momentum. Hypothesis 1 can be confirmed as we find a significant increase in the adoption of lifelong learning. Until 1999 only five organizations - UNESCO, EU, UNICEF, OECD, and the World Health Organization (WHO; table 2) — had mentioned lifelong learning in their documents. A second and more important tipping point occurs around the year 2006, when more than half of the sample (median survival time) has explicitly referred to the idea. 


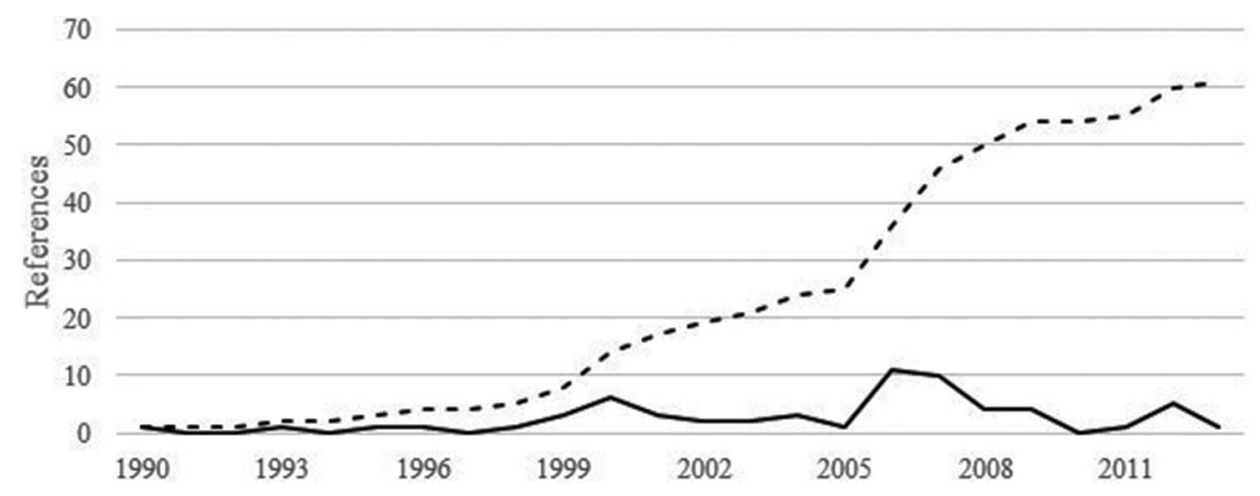

FIG. 1.-The diffusion of lifelong learning 1990-2013. Yearly (solid) and cumulative (dotted) adoptions of lifelong learning, 1990-2013 $(N=61)$. SICA and Howard Hughes Foundation have no reference date and are excluded from quantitative analyses. SourcE.-Data collected by authors.

In order to detect effects of specific factors influencing organizations' cascading references to lifelong learning (hypothesis 2), we applied an event history analysis in three subsequent steps. We first controlled for effects of four organizational characteristics on the timing of adoption: an organization's founding year, the average number of staff during observation period, its type, and geographical area (see table 2 for details).

Positive significant effects on adoption timing can only be attributed to founding year (hypothesis 2.1) and staff (hypothesis 2.2), although the latter has only negligible effect power (risk ratio 1.0) and has been removed in later steps. An important result for founding year indicates that, contrary to the hypothesis, more recently established organizations are more likely to adopt lifelong learning than already established ones (indicated by risk ratio above 1; see table 3). Significant negative effects can be reported for regional banks and labor INGOs (hypothesis 2.3). In contrast, an organization's geographical location (hypothesis 2.4) does not have any significant effect on its risk of adoption although estimates (and risk) are considerably lower for Southern organizations as compared to others (risk ratio .55 for South vs. risk ratios of 1.37 and 2.93 for Northern and mixed organizations, respectively).

Further, we assessed the effect of previous references to lifelong learning on subsequent adoption using split data. The general effect of previous references on the adoption is highly significant (see first row in table 4). Hypothesis 3 can be corroborated; diffusion is explained by contagion.

In order to further specify if and how diffusion occurs along particular channels (the sample's social structure as defined by their organizational properties), a further step (hypothesis 4) examines contagion within particular groups of IOs and compares these channels with diffusion in a global model (beyond individual properties; table 4). 
DIFFUSION OF EDUCATIONAL IDEAS AMONG INTERNATIONAL ORGANIZATIONS

TABLE 3

EFFects on Adoption of Lifelong LeARning

\begin{tabular}{lccrc}
\hline Variable & Parameter Estimate & SE & Wald $\chi^{2}$ & Risk Ratio \\
\hline Founding year & $.15^{* * *}$ & .06 & 6.31 & 1.03 \\
Staff & $.0001^{* * *}$ & .00 & 10.53 & 1.00 \\
Type (R: IGOs) & & & 17.80 & \\
Regional IGOs & -.38 & .57 & 1.01 & .68 \\
Regional banks & $-1.37^{*}$ & .73 & 3.46 & .25 \\
Development Agencies & .45 & .83 & .29 & 1.57 \\
Business INGOs & -.77 & .62 & 1.51 & .46 \\
Labor INGOs & $-1.91^{* * *}$ & .55 & 11.68 & .15 \\
Philanthropic INGOs & -.69 & 1.18 & .34 & 1.99 \\
Area (R: Global) & & & 8.47 & \\
South & -.58 & .57 & 1.01 & .55 \\
North & .322 & .54 & .35 & 1.37 \\
Mixed & 1.07 & .76 & 2.00 & 2.93 \\
\hline
\end{tabular}

NotE. $-\mathrm{R}=$ reference category. Ties have been taken into account using Breslow method. Loglinear method yields similar results, which are not given for brevity. Multicollinearity for all models is negligible. Variance inflation factors for independent variables $<1.37 . \mathrm{SE}=$ standard error.

* $P<.10$.

** $P<.05$.

*** $P<.01$.

Looking at these specific diffusion channels (left column of table 4), we see that the strongest contagion effect can be detected among organizations pertaining to the IGO type (risk ratio 1.10) and, statistically significant, to global organizations (risk ratio 1.12). The model yields more moderate yet significant diffusion among Northern and old organizations. Comparing this channel-specific model with the global model (right column of table 4), in which contagion can occur along and across all channels (i.e., between all

TABLE 4

Estimates of Social Structure Diffusion Model of Lifelong Learning

\begin{tabular}{|c|c|c|c|c|c|c|c|c|}
\hline \multirow[b]{2}{*}{ Variable } & \multicolumn{4}{|c|}{ Channel-Specific Model } & \multicolumn{4}{|c|}{ Global Model } \\
\hline & $\begin{array}{c}\text { Parameter } \\
\text { Estimates }\end{array}$ & SE & $\begin{array}{l}\text { Wald } \\
\chi^{2}\end{array}$ & $\begin{array}{c}\text { Risk } \\
\text { Ratio }\end{array}$ & $\begin{array}{c}\text { Parameter } \\
\text { Estimates }\end{array}$ & SE & $\begin{array}{c}\text { Wald } \\
\chi^{2}\end{array}$ & $\begin{array}{l}\text { Risk } \\
\text { Ratio }\end{array}$ \\
\hline Previous references & & & & & $.02^{* * *}$ & .00 & 15.30 & 1.02 \\
\hline IGOs & .09 & .12 & .60 & 1.10 & $.02^{*}$ & .01 & 2.01 & 1.02 \\
\hline Regional IGOs & .05 & .03 & 1.94 & 1.05 & $.03^{* * *}$ & .01 & 6.54 & 1.03 \\
\hline Regional banks & -.11 & .38 & .08 & .89 & $.03^{*}$ & .02 & 2.00 & 1.03 \\
\hline Development agencies & -.08 & .28 & .09 & .92 & $.05^{* * *}$ & .01 & 7.71 & 1.05 \\
\hline Business INGOs & -2.08 & 2.52 & .68 & .12 & $.03^{*}$ & .02 & 3.02 & 1.03 \\
\hline Labor INGOs & -.06 & .25 & .05 & .94 & $.03^{*}$ & .01 & 3.18 & 1.03 \\
\hline Philanthropic INGOs & -3.47 & 4.41 & .62 & .03 & -.03 & .03 & .52 & .97 \\
\hline North & $.08^{* * *}$ & .02 & 10.37 & 1.09 & $.04^{* * *}$ & .01 & 13.10 & 1.04 \\
\hline South & .01 & .07 & .02 & 1.01 & $.03^{* *}$ & .01 & 5.24 & 1.03 \\
\hline Global & $.11^{* *}$ & .05 & 4.08 & 1.12 & .01 & .01 & 1.77 & 1.01 \\
\hline Mixed & -.15 & .36 & .18 & .86 & .02 & 0.2 & 0.89 & 1.00 \\
\hline Old & $.03^{* * *}$ & .01 & 11.22 & 1.03 & $.02^{* * *}$ & .01 & 7.87 & 1.02 \\
\hline New & .03 & .04 & .68 & 1.03 & $.04^{* * *}$ & .01 & 7.82 & 1.04 \\
\hline
\end{tabular}


TABLE 5

EfFects of "Big Five" (UNESCO, OECD, EU, WB, ILO)

on Adoption of Lifelong Learning

\begin{tabular}{lcccc}
\hline Variable & Parameter Estimate & SE & Wald $\chi^{2}$ & Risk Ratio \\
\hline Prior references & $.45^{* * *}$ & .16 & 7.48 & 1.57 \\
\hline $\begin{array}{l}\text { NotE. }- \text { SE }=\text { standard error. } \\
{ }^{*} P<.10 .\end{array}$ & & & \\
${ }^{* * *} P<.05$. & & & \\
${ }^{* * *} P<.01$. & & & & \\
\end{tabular}

organizations), yields remarkable differences. While the effect of previous references on the adoption of lifelong learning diminishes among the previously important channels, we now find significant contagion effects in those that were negligible before. Here, values become significant for all types of IOs but development agencies in particular. More importantly, effects become stronger for organizations that are based in the Southern hemisphere and those were founded later on during the period of observation. This important finding indicates that these latter are more open to previous references from outside their channels than inside them and will be given attention in the discussion.

Finally, we assessed the impact of the Big Five (UNESCO, EU, OECD, WB, and ILO) on subsequent references (hypothesis 5; see table 5). Estimates for the independent variables are highly significant with a substantial risk ratio of 1.57. We can thus confirm the massive importance of a small set of core organizations in the expansive organizational field under study.

The importance of the Big Five is further underpinned by a complementary key word search based on all organizations' documents revealing a clear core-periphery pattern (table 6). The Big Five account for most of the citations with a considerable lead, thus providing the most authoritative sources for other organizations' conceptions of lifelong learning publications.

\section{Discussion}

We find remarkable worldwide spread of lifelong learning as documented in references by a wide array of global IGOs, regional banks and IGOs, as well

TABLE 6

Core-Periphery Reference Patterns in Lifelong Learning Documents

\begin{tabular}{lr}
\hline Organization & No. of References \\
\hline OECD & 2,981 citations in 112 documents from 35 organizations \\
WB & 2,019 citations in 118 documents from 40 organizations \\
ILO & 1,741 citations in 89 documents from 37 organizations \\
UNESCO & 1,307 citations in 105 documents from 40 organizations \\
EU & 502 citations in 71 documents from 33 organizations \\
\hline \multicolumn{1}{c}{ NotE.--Based on key word search. References from organizations to themselves are } \\
excluded.
\end{tabular}


as INGOs (hypothesis 1). This suggests that the IO field in education is a dynamic and expansive field, which, prima facie, should prompt us to widen our scope in future analyses to do justice to a more diversified set of organizations. At the same time, findings support the assumption that the idea of lifelong learning flows from center to periphery, that is, from global IGOs to all other IOs, from North to South and from older to newer ones. Interestingly, the analysis emphasizes that more recently founded IOs need significantly less time to discover and introduce lifelong learning in their portfolio (hypothesis 2.1). This suggests that more recent IOs may readily draw on already available models of how "to do development" and how "to do education," that is, to position themselves, to internally structure themselves, and to write a "proper" policy or position paper. This finding of isomorphic change is in line with other neoinstitutionalist organization studies and world polity theory (DiMaggio and Powell 1983; Meyer et al. 1997).

Findings are consistent with some major assumptions from the literature on global educational governance and the diffusion of ideas. The focus on the Big Five in research on education in general (Chabbott 2003) and lifelong learning in particular (Jakobi 2006; Schemmann 2007) can thus be confirmed (hypothesis 5). More specifically, the analysis shows that the concept originated among global organizations, those located in the North and those founded before 1990. Global organizations are most influential: UNESCO, EU, OECD, $\mathrm{WB}$, and ILO were important pioneers in this field. Such pioneers have sometimes been called "policy entrepreneurs" (DiMaggio 1988) or "norm entrepreneurs" (Finnemore and Sikkink 1998). UNESCO and OECD, in particular, seem to have drawn on expertise from earlier decades in which lifelong education and recurrent education had been elaborated (Tuijnam and Boström 2002). In addition, global organizations represent an important channel within which organizations pay more attention to their fellow organizations as compared to organizations outside these channels (hypothesis 4). Global organizations are more susceptible to what happens in other global organizations as compared to any other type and area group. This is an important aspect if we want to understand how ideas travel across organization fields.

More importantly, our findings can specify Chabbott's (2003) knowledge production. Some IOs lead the field by rationalizing the knowledge domain. More recent organizations do not need to (re)invent a model that is already out there, enjoying profound legitimacy, and that is elaborated sufficiently vaguely and concretely to be embraced in any locale around the globe without losing its name.

Such a diffusion pattern is primarily explained by the degree of lifelong learning theorization (and educational and developmental thinking in general), which has become very concentrated in the core over time, whereas, once spread, such theorization is hardly found in more peripheral (smaller, 
newer and regional) organizations. Key documents on lifelong learning from some core IOs (e.g., UNESCO and WB) now typically contain several hundred pages with hundreds of scientific references. They provide a highly synthesized state of the art in the field.

Simultaneously, the most important documents dealing with lifelong learning from less prominent IOs do not contain any references at all except for those to the other larger IOs: the League of Arab States (LAS 2008), in its 233 pages-long Plan for the Development of Education in Arab States, has none. Neither does the Organization for Eastern Caribbean States' (OECS 2000) comprehensive Education Planners Handbook. Nor do the Pacific Island Forum's (PIF 2009) Pacific Education Development Framework or all African Union (AU) documents explicitly identify the heritage of these ideas. Exactly the same situation can be found in the 128-page Roadmap for an ASEAN Community (2009).

This does not necessarily imply that "peripheral" IOs conceive their documents without reflecting on advanced research findings; it seems they simply take an intellectual shortcut, importing much of the legitimated and elaborated material already extant. By distilling the state of the art, doing their own research, elaborating it in a condensed format and providing easy access, larger organizations dominate the field through their cognitive authority, that is, their capacity and legitimacy to produce, diffuse and implement educational models.

More generally, we may ask why such large-scale interest in education and lifelong learning has risen at the IO level. Organizations seem to be becoming increasingly "educationalized." This reflects the changing discourse on human development with education being the single most legitimated approach to individual and social development. The wide commitment to lifelong learning is evidence of this, as the idea of lifelong learning might be considered a logical extension of education. This has come about, not because more is now known about the exact impact of education on individual and social development (from economic growth to happiness), but because it is believed that education actually has a tremendous impact on development and because education is valued as a human right (Boli et al. 1985, 47; Ramirez et al. 2006).

The most striking feature in the process analyzed - the speed of its diffusion-is hard to explain by its functionality. The crucial questions are, "how can the very same concept be as helpful for all countries alike, no matter how different they are?" and "why do organizations that have almost no record in educational work so quickly-virtually upon foundation-incorporate a relatively novel concept such as lifelong learning?" We argue that the speed of lifelong learning diffusion can ultimately be explained by the considerable legitimacy the concept and its early carriers already possess and the incentives for young organizations to adopt finalized theories in a complex global environment in which these ideas are (re)produced and diffuse. 
In order to be more certain about the mimetic diffusion of lifelong learning, future studies would have to pay more attention to the institutional conditions for diffusion (Strang and Meyer 1993) through focusing on the content or substance of diffusion (the lifelong learning model itself). Further organization-level analyses could examine whether these references to lifelong learning are merely ceremonial, decoupled from any activities related to it (Meyer and Rowan 1977; Bromley and Scott 2012). Such propositions might enrich the burgeoning discussion about how to better model the behavior of international actors in education (Mundy and Ghali 2009).

\section{Conclusion}

This article addressed the gap in the study of educational governance and diffusion by focusing on international organizations as an analytical level in its own right. The worldwide proliferation of IOs creates an organizational field conducive to the diffusion of educational models. The event history analysis has shown that lifelong learning as a recent conceptual innovation has taken center stage within the worldwide educational agenda. Largely radiating from a core of established global and Northern IGOs into a more diverse and growing international organizational landscape, the diffusion of lifelong learning marks unprecedented interest in education and more peripheral (younger, smaller and regional) organizations' search for ready-made conceptual blueprints that have already attained legitimacy. Using the example of lifelong learning, we show how a Western idea has spread around the organizational world beyond nation-states. Such a finding complements neoinstitutionalist research that has provided convincing evidence for increasing similarities in national education systems by focusing on upper-level actors that might catalyze such dynamics on a much wider scale as ever before. We can now add that similar conceptual or ideational isomorphism occurs at the IO level.

Although highly heterogeneous in type, history, and staff as well as in terms of the geographical, cultural, socioeconomic, and political background they represent, the IOs analyzed share a similar belief system derived from a powerful script: disinterested, rationalized and scientized "others" that pursue the abstract world cultural goods of justice and progress and that offer the same solution to a variety of social and economic problems. With education (and its recent specification: lifelong learning) becoming the single most legitimated means to achieve these goals, borders between rich and poor, North and South, intergovernmental and nongovernmental, young and old disappear. In this sense, a unified organizational field in education provides an integrating global discursive frame that makes national isomorphism an evermore likely outcome, with alternative or opposed discourses largely vanishing.

Although we confirm and specify the relevance of core organizations as influential knowledge producers, many actors from our sample have not yet 
received any attention from the relevant literature. As "receptors" and "nodes of diffusion" (Jakobi 2012) in more local settings, they should not be excluded from analyses. More importantly, the built-in field hierarchy found here is not necessarily a given and future studies would have to reassess the internal field dynamics over time. Here, the relatively recent emergence of the OECD and WB as major educational "theorists" might suggest shifting centers of cognitive authority in the field.

The implications of our analysis go beyond the case of lifelong learning and include a refined theoretical and methodological apparatus to study the dynamics of the global educational agenda in general with IOs being an important unit of analysis, both in its own right and at the interplay between international discourse and national policy making.

\section{References}

Aalen, Odd, Ornulf Borgan, and Hakon Gjessing. 2008. Event History Analysis: A Process Point of View. New York: Springer.

ASEAN. 2009. Roadmap for an ASEAN Community 2009-2015. Jakarta. http://www .meti.go.jp/policy/trade_policy/asean/dl/ASEANblueprint.pdf.

Boli, John, Francisco O. Ramirez, and John W. Meyer. 1985. "Explaining the Origins and Expansion of Mass Education." Comparative Education Review 29 (2): 14570.

Boli, John, and George M. Thomas, eds. 1999. "INGOs and the Organization of World Culture." In Constructing World Culture International Nongovernmental Organizations since 1875. Stanford, CA: Stanford University Press.

Borgatti, Stephen P., and Pacey C. Foster. 2003. "The Network Paradigm." Journal of Management 29 (6): 991-1013.

Bromley, Patricia. 2010. "The Rationalization of Educational Development: Scientific Activities among International Non-Governmental Organizations." Comparative Education Review 54 (4): 577-601.

Bromley, Patricia, and Walter W. Powell. 2012. "From Smoke and Mirrors to Walking the Talk: Decoupling in the Contemporary World." Academy of Management Annals 6 (1): 483-530.

Chabbott, Colette. 2003. Constructing Education for Development: International Organizations and Education for All. New York: Routledge.

Dale, Roger. 2005. "Globalisation, Knowledge Economy, and Comparative Education." Comparative Education 41 (2): 117-49.

Daniel, John. 2009. "Learning for Development: the work of the Commonwealth of Learning." In The Routledge International Handbook of Lifelong Learning, ed. P. Jarvis. London: Routledge.

Deacon, B. 2007. Global Social Policy and Governance. London: Sage.

DiMaggio, P. J. 1988. "Interest and Agency in Institutional Theory." In Institutional Patterns and Organizations. Culture and Environment, ed. L. G. Zucker. Cambridge, MA: Ballinger. 
DiMaggio, P. J., and W. W. Powell. 1983. “The Iron Cage Revisited: Institutional Isomorphism and Collective Rationality in Organizational Fields." American Sociological Review 48 (2): 147-60.

Drori, Gili S., John W. Meyer, Francisco O. Ramirez, and Evan Schofer. 2003. Science in the Modern World Polity: Institutionalization and Globalization. Stanford, CA: Stanford University Press.

Duke, Chris. 1999. "Research in Adult Education: Current Trends and Future Agenda." In World Trends in Adult Education Research. Hamburg: UNESCO Institute for Education.

Field, John. 2006. Lifelong Learning and the New Educational Order. Stoke-on-Trent: Trentham.

Finnemore, Martha. 1993. "International Organizations as Teachers of Norms: The United Nations Educational, Scientific, and Cultural Organization and Science Policy." International Organization 47 (4): 565-97.

Finnemore, Martha, and Kathrin Sikkink. 1998. "International Norm Dynamics and Political Change." International Organization 52 (4): 887-917.

Hannan, Michael T., and John Freeman. 1984. "Structural Inertia and Organizational Change." American Sociological Review 49 (2): 149-64.

Jakobi, Anja P. 2006. "The Worldwide Norm of Lifelong Learning: A Study of Global Policy Development." PhD diss., University of Bielefeld.

Jakobi, Anja P. 2007. "Converging Agendas in Education Policy-Lifelong Learning in World Bank and International Labour Organization." In New Arenas of Education Governance: The Impact of International Organizations and Markets on Educational Policy Making, ed. K. Martens, A. Rusconi, and K. Leuze. Basingstoke: Palgrave Macmillan.

Jakobi, Anja P. 2012. "Facilitating Transfer: International Organizations as Central Nodes for Policy Diffusion." In World Yearbook of Education: Policy Borrowing and Lending, ed. G. Steiner-Khamsi and F. Waldow. London: Routledge.

Jarvis, Peter. 2010. Adult Education and Lifelong Learning. Theory and Practice. London: Routledge.

LAS. 2008. A Plan for the Development of Education in the Arab Countries. Tunis. http:/ / www.alecso.org.tn/lng/images/stories/fichiers/en/KHOTTA\%202008/KHOTTA $\% 202008 \%$ 20Eng.pdf.

Lee, M., T. Thayer, and N. Madyun. 2008. “The Evolution of the European Union's Lifelong Learning Policies: An Institutional Learning Perspective.” Comparative Education 44 (4): 445-63.

Martens, Kerstin, and Dennis Niemann. 2010. Governance by Comparison: How Ratings and Rankings Impact National Policy-Making in Education. Bremen: University of Bremen.

Meyer, John W., John Boli, George M. Thomas, and Francisco O. Ramirez. 1997. "World Society and the Nation-State." American Journal of Sociology 103 (1): 14481.

Meyer, John W., and Brian Rowan. 1977. "Institutionalized Organizations: Formal Structure as Myth and Ceremony.” American Journal of Sociology 83 (2): 340-63.

Milana, M. 2012. "Political Globalization and the Shift from Adult Education to Lifelong Learning." European Journal for Research on the Education and Learning of Adults 3 (2): 103-17. 
Milana, M. 2015. "Global Polity in Adult Education and UNESCO: Landmarking, Brokering, and Framing Policy." Globalisation, Societies, and Education 14 (2): 203-26. Mundy, Karen. 2006. "The Evolution of Educational Multilateralism from 1945 to 2005." In Bildung International: Historische Perspektiven und aktuelle Entwicklungen, ed. E. Fuchs. Würzburg: Ergon.

Mundy, Karen. 2007. "Educational Multilateralism-Origins and Indications for Global Governance." In New Arenas of Education Governance: The Impact of International Organizations and Markets on Educational Policy Making, ed. K. Martens, A. Rusconi, and K. Leuze. Basingstoke: Palgrave Macmillan.

Mundy, K., and M. Ghali. 2009. "International and Transnational Policy Actors in Education: A Review of the Research." In Handbook on Educational Policy Research, ed. D. Plank, G. Sykes, and B. Schneider. New York: Routledge.

Nazio, Tiziana. 2008. Cohabition, Familiy and Society. New York: Routledge.

OECD CRS (Creditor Reporting System). 2014. "Resource Organization for Economic Cooperation and Development." https://stats.oecd.org/Index.aspx?bDataSetbCode $=$ CRS1.

OECS. 2000. OECS Education Planner's Handbook: For National Capacity Building in Performance Monitoring. Tortola. http://www.oecs.org/edmu-documents/.../147-educatiion -planners-handbook-ver-1.

Papadopoulos, George. 2002. "Lifelong Learning and the Changing Policy Environment." In International Perspectives on Lifelong Learning. From Recurrent Education to the Knowledge Society, ed. D. Istance, H. G. Schuetze, and T. Schuller. Buckingham: Open University Press.

Papadopoulos, George. 2006. "The OECD and the Evolution of National Policies for Education 1960-1990: An Overview." In Supranational Regimes and National Education Policies. Encountering Challenge, ed. J. Kallo and R. Rinne. Joensuu: Finnish Educational Research Association.

Parreira do Amaral, M. 2010. "Regime Theory and Educational Governance: The Emergence of an International Education Regime.” In International Educational Governance (International Perspectives on Education and Society, Vol. 12), ed. S. Karin Amos. Bingley: Emerald Group Publishing.

PIF. 2009. Pacific Education Development Framework (PEDF), 2009-2015. Suva. http:// www.forumsec.org.fj/resources/uploads/attachments/documents/Pacific\%20Education \%20Development\%20Framework\%202009-2015.pdf.

Powell, W. W., and P. J. DiMaggio. 1991. The New Institutionalism in Organizational Analysis. Chicago: University of Chicago Press.

Power, Michael. 2004. "Counting, Control and Calculation: Reflections on Measuring and Management." Human Relations 57 (6): 765-83.

Ramirez, Francisco O., and John Boli. 1987. "The Political Construction of Mass Schooling: European Origins and Worldwide Institutionalization." Sociology of Education 60 (1): 2-17.

Ramirez, Francisco O., Xiaowei Luo, Evan Schofer, and John Meyer. 2006. "Student Achievement and National Economic Growth." American Journal of Education 113 (1): 1-29.

Ramirez, Francisco O., J. W. Meyer, and J. Lerch. 2016. "World Society and the Globalization of Education Policy." In The Handbook of Global Education Policy, ed. K. Mundy et al. New Jersey: Wiley-Blackwell. 
Rivera, William M. 2009. “The World Bank's View of Lifelong Learning: Handmaiden of the Market." In The Routledge International Handbook of Lifelong Learning, ed. P. Jarvis. London: Routledge.

Rogers, Everett M. 2003. Diffusion of Innovations. 5th ed. New York: Free Press.

Rubenson, K. (2015). "Framing the Adult Learning and Education Policy Discourse: The Role of the OECD." In Global Perspectives on Adult Education and Learning Policy, ed. M. Milana and T. Nesbit. New York: Macmillan.

Rutkowski, David. 2007. "Converging Us Softly: How Intergovernmental Organizations Promote Neoliberal Education Policy." Critical Studies in Education 48 (2): 303-26.

Schemmann, Michael. 2007. Internationale Weiterbildungspolitik und Globalisierung. Bielefeld: Bertelsmann.

Scherrer, Christoph. 2007. "GATS - Commodifying Education via Trade Treaties." In New Arenas of Education Governance, ed. K. Martens, A. Rusconi, and K. Leuze. Basingstoke: Palgrave Macmillan.

Schuetze, Hans G., and Catherine Casey. 2006. "Models and Meanings of Lifelong Learning: Progress and Barriers on the Road to a Learning Society." Compare 36 (3): 279-87.

Schuller, Tom. 2009. "The OECD and Lifelong Learning." In The Routledge International Handbook of Lifelong Learning, ed. P. Jarvis London: Routledge.

Scott, W. R. 1994. "Conceptualizing Organizational Fields: Linking Organizations and Societal Systems.” In Systemrationalitat und Partialinteresse, ed. H. Derlien, U. Gerhardt, and F. Scharpf. Baden-Baden: Nomos.

Scott, W. R. 2013. Institutions and Organizations. Ideas, Interests, and Identities. Thousand Oaks, CA: Sage.

Steiner-Khamsi, Gita. 2012. "Understanding Policy Borrowing and Lending: Building Comparative Policy Studies." In Policy Borrowing and Lending. World Yearbook of Education 2012, ed. G. Steiner-Khamsi and F. Waldow. London: Routledge.

Stinchcombe, Arthur L. 1965. "Social Structure and Organizations." In Handbook of Organizations, ed. J. G. March. Chicago: Rand McNally.

Strang, D., and J. W. Meyer. 1993. "Institutional Conditions for Diffusion." Theory and Society 22 (4): 487-511.

Strang, D., and S. A. Soule. 1998. "Diffusion in Organizations and Social Movements: From Hybrid Corn to Poison Pills." Annual Review of Sociology 24:26590.

Strang, D., and N. B. Tuma. 1993. "Spatial and Temporal Heterogeneity in Diffusion." American Journal of Sociology 99 (3): 614-39.

Strang, David. 1991. "Adding Social Structure to Diffusion Models. An Event History Framework.” Sociological Methods and Research 19 (3): 324-53.

Tuijman, A., and A.-K. Boström. 2002. "Changing Notions of Lifelong Education and Lifelong Learning." International Review of Education 48 (1-2): 93-110.

Tuma, N. B., and M. T. Hannan. 1984. Social Dynamics: Models and Methods. Orlando, FL: Academic Press.

Union of International Organizations. 2016. Yearbook of International Organizations 1954-2013. Leiden: Brill.

Wejnert, Barbara. 2002. "Integrating Models of Diffusion of Innovations: A Conceptual Framework.” Annual Review of Sociology 28:297-326. 
ZAPP AND DAHMEN

Wiseman, A. W., and D. P. Baker, eds. 2005. "Global Trends in Education Policy." In International Perspectives on Education and Society Series. Vol. 6. Oxford: Elsevier. Yeates, Nicola. 2008. "The Idea of Global Social Policy." In Understanding Global Social Policy, ed. N. Yeates. Bristol: Policy. 